\title{
1 Photovoltaic Solar Electrodialysis with Bipolar
}

\section{Membranes}

3 Marta Herrero-Gonzalez*, Pedro Diaz-Guridi, Antonio Dominguez-Ramos,

4 Raquel Ibañez, Angel Irabien

5 Departamento de Ingenierías Química y Biomolecular, Universidad de Cantabria,

6 Avenida de los Castros s/n, 39005 Santander, Cantabria, Spain

$7 \quad{ }^{*}$ Correspondence author: Tel.: +34 942 202028; E-mail address: herrerogma@unican.es

8 (Marta Herrero-Gonzalez)

9

10

\section{Abstract}

Electrochemical process like Electrodialysis (ED) and Electrodialysis with Bipolar Membranes (EDBM) can contribute to the production of freshwater and to the valorization of waste streams. In particular, EDBM can valorise the waste from desalination technologies using electric power, producing acids $(\mathrm{HCl})$ and basis $(\mathrm{NaOH})$ from seawater rejected brines. The use of a variable current intensity coming from a lowcarbon source such as photovoltaic (PV) solar energy means a decrease of the associated carbon footprint of the obtained products. In this work, the reduction of the specific energy consumption (SEC) of the acid from an EDBM process thanks to a feedback control loop under variable current intensity is presented. The EDBM process works in continuous or semi-continuous mode under constant or variable current intensity by means of a PV solar array simulator for 30 hours. A concentration around $1 \mathrm{~mol} \cdot \mathrm{L}^{-1} \mathrm{HCl}$ has been obtained in all experiments even under variable current intensity. A noticeable drop in the SEC from a reference value of $7.3 \mathrm{kWh} \cdot \mathrm{kg}^{-1} \mathrm{HCl}$ (constant current intensity) to $4.4 \mathrm{kWh} \cdot \mathrm{kg}^{-1} \mathrm{HCl}$ (variable current intensity and feedback control loop) was reported.

Keywords: Brine valorization; Bipolar membrane electrodialysis; Photovoltaic solar energy; Acid production; Base production 


\section{Introduction}

Electrochemical process like Electrodialysis (ED) and Electrodialysis with Bipolar Membranes (EDBM) can contribute to the production of freshwater and to the valorization of waste streams. In particular, EDBM is capable of producing acids such as $\mathrm{HCl}$ and bases such as $\mathrm{NaOH}$ from the waste of the desalination technologies in the form of brines using electricity as a driver. Indeed, the most critical limitation of using EDBM for acid and basis production is related to this energy consumption, which also affects the operation costs [1]. An example of reported values for the Specific Energy Consumption (SEC) of EDBM is between $7.5 \mathrm{kWh} \cdot \mathrm{kg}^{-1} \mathrm{HCl}$ and $8.3 \mathrm{kWh} \cdot \mathrm{kg}^{-1} \mathrm{HCl}$ [2]. Therefore, the generation of the demanded electrical energy for the EDBM will have a certain carbon footprint, depending on the electricity mix employed. To prevent this indirect environmental implications, in terms of carbon footprint of the EDBM technology due to its relatively high SEC, a straightforward way to circumvent this undesired situation is the use of a low-carbon renewable power source.

In general, the direct integration of desalination with low-carbon renewable energies is mainly accomplished by wind and PV solar power and typically restricted to autonomous small capacity plants [3]. The direct coupling of electrochemical processes and renewable energy for polluted streams [4] or even desalination [5] are well-known approaches in the literature in order to avoid the carbon footprint associated with a large energy consumption. The main advantage of this kind of strategies is that, in terms of primary energy, the SEC per unit of treated volume is almost free of environmental burdens, which makes the process to have a clear eco-innovative behavior. Consequently, the supply of direct current (DC) to electrochemical processes achieved by PV solar energy is described as an interesting alternative (see Table 1) and does not need extra electrical transformations (AC to DC). Other renewable sources such as wind power may have been chosen, but the excellent modularity capacity and potential future developments make PV solar the most desirable option in general.

Published literature regarding PV solar energy combined with electrochemical technologies featured two essential characteristics. The first one is the fact that the DC power supply is typically connected to a regulator system, providing a smooth DC output thanks to batteries. The second feature is that the integrated PV process operates in batch mode or continuous mode but only during short time operations, as shown in Table 1 for the ED technology. This situation of short times strangles the possibility to analyze a 
critical item such as the solar irradiation profiles, which lead to a variable current intensity for the chosen EDBM process. Therefore, the applied current intensity is time-dependent. Indeed, the stochastic nature of the solar irradiation makes that a proper design and operation is needed to circumvent the application of the time-dependent electricity input rather than a constant (or galvanostatic) one.

The prospect of coupling the operation of EDBM in continuous mode instead of batch has been scarcely referenced and no studies were found together with the integration of naturally-variable current input in a whole day. Indeed, the experimental total time of electrochemical processes coupled to PV solar sources tends to be below 500 minutes. It seems obvious that there is a lack of studies for continuous mode operation, which is the normal mode of operation for large-flowrate facilities as in desalination plants, and even less if coupled to PV solar energy.

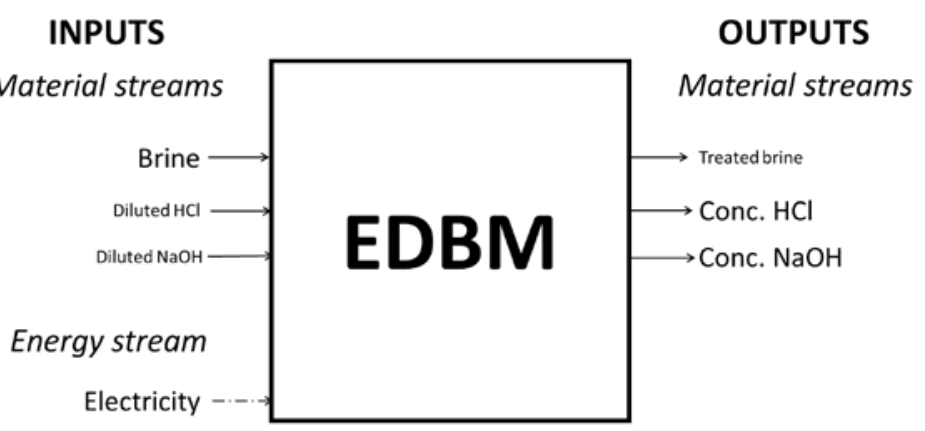

Figure 1. Flowsheet of the EDBM plant.

For this reason, a novel configuration integrating EDBM with a variable current intensity is depicted in Figure 1. As it can be seen, there are three material input streams: brine, diluted acid $(\mathrm{HCl})$, and diluted base $(\mathrm{NaOH})$; one energy input as electricity in the form of direct current (constant or variable current intensity); and three output material streams: treated brine, concentrated acid $(\mathrm{HCl})$ and concentrated base $(\mathrm{NaOH})$. As the current intensity is simulating the output of a PV solar array, the benefits in terms of using renewable power sources are clear due to the low-carbon footprint per unit of electric energy. 
97

Table 1. Selected references of ED and EDBM systems powered by constant and variable current intensity, operating in batch and continuous mode. B stands for batch and Cnt for continuous.

\begin{tabular}{|c|c|c|c|c|c|c|c|c|c|}
\hline \multirow{2}{*}{\multicolumn{2}{|c|}{$\begin{array}{c}\text { Power Supply } \\
\text { Operation } \\
\text { mode }\end{array}$}} & \multicolumn{4}{|c|}{ Constant (grid mix) } & \multicolumn{4}{|c|}{ Variable (Photovoltaic) } \\
\hline & & B & $\begin{array}{l}\text { Time } \\
\text { (min) }\end{array}$ & Cnt & $\begin{array}{l}\text { Time } \\
\text { (min) }\end{array}$ & B & $\begin{array}{l}\text { Time } \\
\text { (min) }\end{array}$ & Cnt & $\begin{array}{l}\text { Time } \\
\text { (min) }\end{array}$ \\
\hline \multirow{7}{*}{ 행 } & \multirow{4}{*}{ ED } & [6] & 25 & [7] & - & [8] & 50 & & \\
\hline & & [7] & - & [9] & $\begin{array}{l}1,500- \\
3,600\end{array}$ & [10] & $90-120$ & & \\
\hline & & {$[9]$} & $\begin{array}{l}1,500- \\
3,600\end{array}$ & [11] & - & & & & \\
\hline & & & & [12] & 150 & & & & \\
\hline & \multirow{3}{*}{ EDBM } & {$[13]$} & 30 & [2] & 420 & & & & \\
\hline & & [14] & 480 & & & & & & \\
\hline & & [15] & 180 & & & & & $\begin{array}{l}\text { This } \\
\text { work }\end{array}$ & 1,800 \\
\hline
\end{tabular}

The use of a large current intensity can lead to the fact that most of the injected energy is wasted. Even if the generation of acid is assumed to be proportional to the applied current [16], a crossover phenomenon is suggested here to explain the plateau in the acid character versus the applied current [17-19]. Therefore, the additional amount of injected electricity is not transformed into a higher acid/base concentration, leading to higher SEC values.

Taking into account the previous considerations, the aim of this work is the reduction of the SEC of the acid and base production from saline concentrates by means of EDBM under variable current intensity. As a case of study, the production of $\mathrm{HCl}$ and $\mathrm{NaOH}$ from synthetic seawater desalination brines is selected. The EDBM process operates with a variable current intensity, which simulates the behavior of a real PV solar module under 
a predetermined solar irradiation profile connected directly to the lab-scale stack. Special emphasis regarding the SEC of the produced acid is provided, considering the fact it is the target product usually reported in the literature. Constant current intensity is studied as reference. The effect of not using the feedback control loop is also included as reference.

\section{Experimental methodology}

\subsection{Lab scale experimental set-up}

All the experiments in this work were performed in a modified PCCell (Germany) bench scale laboratory ED system, composed of different elements as shown in Figure 2. The main modifications include the peristaltic pumps to work in continuous or semicontinuous mode as well as the SCADA system and measurement equipment. The individual feedback control loops for the $\mathrm{pH}$ of the acid and the conductivity in the brine are also inserted in Figure 2. The controlled variable is the $\mathrm{pH}$ of the concentrated acid stream. A set-point is fixed for the $\mathrm{pH}$ of the acid. The measured variable is therefore the $\mathrm{pH}$ of the acid. The manipulated variable is the flowrate of the diluted $\mathrm{HCl}$ stream. Due to the overflow configuration, this flowrate matches exactly the flowrate of the concentrated $\mathrm{HCl}$ stream. Disturbances in the $\mathrm{pH}$ value are due to the variable current intensity. Zero flowrate of the input diluted $\mathrm{HCl}$ will tend to reduce the $\mathrm{pH}$ until the maximum value (concentration effect). A relatively large flowrate of the diluted $\mathrm{HCl}$ stream will reduce the $\mathrm{pH}$ (dilution effect). As later explained, the use of this control loop will help at reducing the SEC. An additional feedback control loop is included regarding the conductivity of the brine tank. For this one, the controlled variable is the conductivity of treated brine stream. A set-point is fixed for the conductivity of the brine. The measured variable is the brine conductivity. The manipulated variable is the flowrate of the input brine stream. The individual components of the lab-scale plant are described next. 


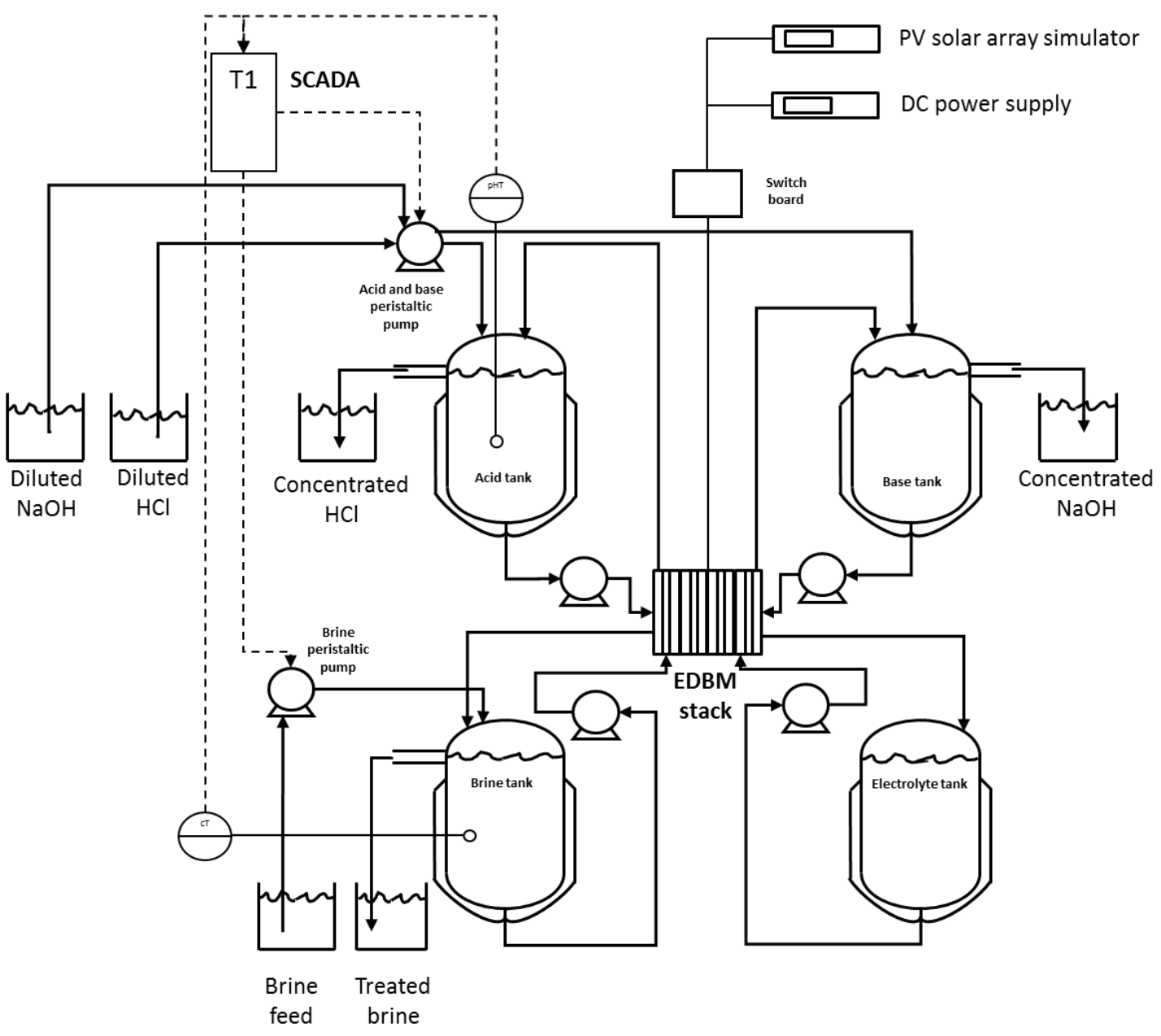

Figure 2. Set up of the lab scale EDBM process. Level, voltage, and current intensity transmitters as well as other elements are not included for simplicity

a. Cell stack and membranes

The commercial electrodialysis cell used is composed of two electrodes made of titanium and coated with ruthenium oxide. The effective area of the cathode and the anode is $100 \mathrm{~cm}^{2}$ (square, $10 \mathrm{~cm}$ each side). Commercial heterogeneous polyethylene based anion (AM-PP RALEX) and cation (CM-PP RALEX) exchanges membranes were acquired from Mega (Czech Republic). Commercial bipolar membranes (Fumasep FBM) were purchased from Fumatech (Germany). The configuration of the stack is displayed in Figure 3, following the next sequence CEM/AEM/BP/CEM/CEM (or abbreviated as CABCC+ configuration). Same membrane type and configuration than in previous works [14] have been selected in order to be able to compare the obtained results. 


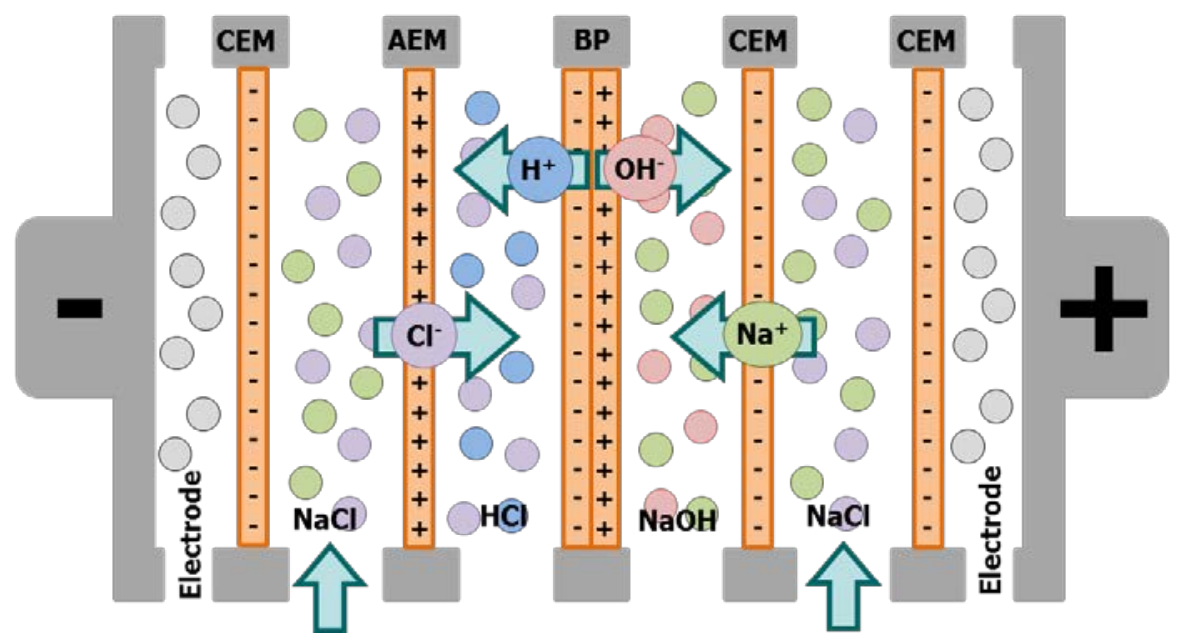

Figure 3. EDBM stack configuration.

\section{b. Power supply}

A commercial power supply (Statron, Germany) is integrated into the modified bench scale laboratory ED system to be used when constant applied current intensity is considered. This power supply is able to provide a maximum current of $22 \mathrm{~A}$ and a maximum voltage of $36 \mathrm{~V}$ as nominal values.

c. PV solar array simulator for the variable current intensity

A PV solar array simulator (Chroma, Netherlands) was coupled to the modified bench scale laboratory ED system. This power supply simulates the electrical output of a PV solar array, once defined a set of parameters as in Table 2, based on a certain solar irradiation profile. Through the introduction of the panel parameters and the irradiation and temperature curves chosen by the user, the software provides the current intensityvoltage (I-U) and power-voltage (P-U) operation curves. The relationship between the applied current intensity (I) and the voltage (U) is determined by the total ohmic resistance between the electrodes of the stack and is not fixed by the simulator. Therefore, the simulator behaves such as a real PV solar array. The selected parameters for this case study are shown in Table 2 [20]. The mathematical model is the set of equations that correlate the voltage and current intensity from the PV solar array at a certain temperature and solar irradiation. The FF is the ratio between the power at the maximum power point under standard reference conditions and the hypothetical power given by the open circuit voltage and the short current intensity. The use of a PV solar array simulator provides a great flexibility thus any solar irradiation profile can be chosen. 
Table 2. Parameters used in the operation in the solar array simulator.

\begin{tabular}{|l|l|l|l|}
\hline Parameters & Parameter name & Value & Units \\
\hline Mathematical model & I-V Model & SANDIA & - \\
\hline $\begin{array}{l}\text { Voltage power } \\
\text { maximum } \\
\text { point) }\end{array}$ & $\mathrm{V}_{\mathrm{mp}}$ & 34.4 & $\mathrm{~V}$ \\
\hline $\begin{array}{l}\text { Power (at maximum } \\
\text { power point) }\end{array}$ & $\mathrm{P}_{\mathrm{mp}}$ & 160 & $\mathrm{~W}$ \\
\hline Fill Factor & $\mathrm{FF}$ & 0.68 (Std. Crystalline) & - \\
\hline $\begin{array}{l}\text { Exposed area } \\
\text { Maximum } \\
\text { efficiency }\end{array}$ & $\mathrm{A}_{\mathrm{PV}}$ & 1.125 & $\mathrm{~m}^{2}$ \\
\hline
\end{tabular}

181

d. pHmeter and conductivimeter

Continuous monitoring and control of conductivity in the brine stack and $\mathrm{pH}$ in the acid stack are provided by two probes connected to a transmitter (Endress+Hauser, Germany).

\section{e. Refrigerator}

In order to control the temperature of the liquid in the different compartments of the stack, a refrigeration bath was used from PolyScience (USA). The coolant flows through the volume of the jacket of the tanks.

\section{f. Control via SCADA}

The experimental set-up is controlled by a PLC (CX-Programmer) connected to a SCADA (Supervisory Control and Data Acquisition) system (CX-Supervisor). Both CXProgrammer and CX-Supervisor, belong to the CX-One package (OMRON, Japan). The customized program allows the operator to select between power supplies (power supply/PV solar array simulator), to record the $\mathrm{pH}$ and conductivity; and to manipulate the value of variables such as the input feed flowrate. The feedback control loop is inserted in the customized SCADA program. 
g. Tanks and peristaltic pumps

Four individual jacked glass tanks with a capacity of 2.3 L (maximum volume before overflowing) were used for the recirculation through each compartment in the stacks (brine, acid, base and electrode). Two peristaltic pumps Watson-Marlow 323Du (England) were used for the feed and the product (two heads). To guarantee the same value for the inlet and the output flow, the overflow of each tank was used. Due to the good mixing in the tanks, the concentration of the overflowing products and the treated brine is the same in the collected streams and in the tanks.

\section{h. Solutions prepared for the experiments}

Model desalination synthetic brines from a RO desalination plant in operation located in Las Aguilas (Spain) [14,21] were used in the experiments. The salt tank was initially loaded with $0.5 \mathrm{~mol} \cdot \mathrm{L}^{-1} \mathrm{NaCl}$, being the feed inlet $1 \mathrm{~mol} \cdot \mathrm{L}^{-1} \mathrm{NaCl}$. The $\mathrm{NaCl}$ used was extra pure grade and purchased from Scharlau. The initial acid and base concentrations in the acid and base tanks were $1 \mathrm{~mol} \cdot \mathrm{L}^{-1} \mathrm{HCl}$ and $1.5 \mathrm{~mol} \cdot \mathrm{L}^{-1} \mathrm{NaOH}$ respectively, according to the concentrations reached in a batch operation mode in a previous work [14]. The inlet concentration was $0.1 \mathrm{~mol} \cdot \mathrm{L}^{-1} \mathrm{HCl}$ for the acid and $0.1 \mathrm{~mol} \cdot \mathrm{L}^{-1} \mathrm{NaOH}$ for the basis. Both acid and base were ACS grade and purchased from Panreac. Two different solutions were used for the electrode compartment: $0.5 \mathrm{~mol} \cdot \mathrm{L}^{-1} \mathrm{NaOH}$ and $0.5 \mathrm{~mol} \cdot \mathrm{L}^{-1}$ $\mathrm{Na}_{2} \mathrm{SO}_{4}$ (ACS grade, Scharlau). Mili-Q water was used to prepare the input streams and the tanks solutions. Same concentrations than in previous works [14] have been selected in order to be able to compare the obtained results.

\subsection{Experimental procedure}

The experimental system has been operated in continuous (all flowrate are constant and different from zero) or semi-continuous (flowrates maybe zero) mode. Acid ( $\mathrm{HCl}$ ) and base $(\mathrm{NaOH})$ are generated with no liquid accumulation due to the overflows. Every experiment did last 30 hours, distributed in three days, operating 10 hours per day. The flowrate of the stream that recirculates the liquid from each tank to each corresponding compartment through the EDBM cell was $60 \mathrm{~L} \cdot \mathrm{h}^{-1}$ (centrifugal pumps in the center of Figure 2). The temperature was set to approximately $15^{\circ} \mathrm{C}$ thanks to the tanks being jacketed. Four experiments have been performed (E-C, E-V1, E-V2 and E-V3). The corresponding experimental conditions are summarized in Table 3. Current intensity for 
the experiment E-C and the membranes for all the experiments were chosen from previous works in batch mode [21].

\section{a. Constant current intensity experiment (E-C)}

Initially, the continuous mode is tested considering constant current intensity as a reference, leading to experiment E-C. Application of a constant current density can be used as a benchmark for the comparison when the current density is variable. In the E-C experiment, a constant current intensity of 2.2 A given by the power supply was applied. This current density was determined based on the results from [21] for this case study.

\subsubsection{Variable current intensity with no feedback control loop (E-V1 and E-V2)}

To fulfill the aim of the work, the influence of the variable current intensity was analyzed. Consequently, only the current intensity profile was changed from E-C (constant) to E-V1 and E-V2 (variable). Continuous mode was the chosen operating mode (constant flowrate different from zero). For both E-V1 and E-V2 experiments, the solar array simulator was employed as power supply. An average irradiation corresponding to the month of July in Almería (southeast, Spain) obtained from PV-GIS database [22] was selected. This irradiation profile was chosen due to the large solar irradiation values in this area of Spain. Almería is a southeast region within Spain with important water scarcity problems and desalination capacities [23]. A maximum irradiation of $960 \mathrm{~W} \cdot \mathrm{m}^{-}$

2 is obtained at the central hours of the day in that location in July. In addition, it is clear that these conditions should be favorable to the process: the possibility of further scaleup of EDBM powered by PV will be necessarily completed in a region with this kind of facility demands. The difference between E-V1 and E-V2 is the nature of the electrolyte used in the electrode tank. Finally, $0.5 \mathrm{~mol} \cdot \mathrm{L}^{-1} \mathrm{NaOH}$ and $0.25 \mathrm{~mol} \cdot \mathrm{L}^{-1} \mathrm{Na}_{2} \mathrm{SO}_{4}$ solutions were used as an electrolyte in the E-V1 and E-V2 experiments, respectively.

\subsubsection{Variable current intensity with feedback control loop (E-V3)}

The possibility of increasing the net production of $\mathrm{HCl}$ (thus a larger flowrate) by controlling the $\mathrm{pH}$ of the $\mathrm{HCl}$ product under the same irradiation profile as in $\mathrm{E}-\mathrm{V} 1$ and E-V2 was analyzed in E-V3 (July, Almeria) under semi-continuous mode (flowrate can be zero). The inlet flowrates can be zero or a fixed value according to the set-point entered via the SCADA program. The peristaltic pump responsible for the flowrate to the acid and basis tanks is only activated at $4 \mathrm{~mL} \cdot \mathrm{min}^{-1}$ when the $\mathrm{pH}$ in the acid tank is below 0.1 . 
268 The peristaltic pump responsible for the flowrate to the salt tank is only activated at 8 $269 \mathrm{~mL} \cdot \mathrm{min}^{-1}$ when the conductivity in the salt tank is below $50 \mathrm{mS} \cdot \mathrm{cm}^{-1}$.

270 As a summary, E-C is the benchmark experiment under constant current intensity, 271 while E-V1, E-V2, and E-V3 show the effect of the variable current intensity (simulated 272 by the solar irradiation profile). E-V1 and E-V2 were run in continuous mode (no 273 feedback control loop) while E-V3 was run in semi-continuous mode (feedback control 274 loop).

\subsection{Analytical methods}

277 Samples were withdrawn every two hours for the measurement of $\mathrm{pH}$ and 278 conductivity. Acid and base titration, using analytical grade reagents, was also performed. 279 The concentration of $\mathrm{Cl}^{-}, \mathrm{SO}_{4}{ }^{2-}$, and $\mathrm{Na}^{+}$were determined by ion chromatography 280 (Dionex ICIS-1100 for anions and Dionex DX-120 for cations, Dionex Corp., (USA)). 281 Control samples were included in the analytical procedure to guarantee the validity of the 282 results. The record of current intensity and voltage was completed by the data collection 283 tool used in the SCADA program. 
Table 3. Description of four performed experiments.

\begin{tabular}{|c|c|c|c|c|c|c|c|c|c|c|}
\hline \multirow{3}{*}{$\begin{array}{l}\text { Experiment } \\
\text { code }\end{array}$} & \multirow{3}{*}{$\begin{array}{l}\text { Current } \\
\text { intensity } \\
\text { mode }\end{array}$} & \multirow{3}{*}{$\begin{array}{l}\text { Operation } \\
\text { mode }\end{array}$} & \multirow{3}{*}{$\begin{array}{l}\begin{array}{l}\text { Flowrate } \\
\text { (salt tank) }\end{array} \\
\mathrm{mL} \cdot \mathrm{min}^{-1}\end{array}$} & \multirow{3}{*}{$\begin{array}{l}\text { Flowrate } \\
\text { (acid/base tank) } \\
\mathrm{mL} \cdot \mathrm{min}^{-1}\end{array}$} & \multirow{3}{*}{$\begin{array}{l}\text { Electrode } \\
\text { solution }\end{array}$} & \multirow{3}{*}{$\begin{array}{c}\text { NaCl } \\
\text { input } \\
\text { stream } \\
{\mathrm{mol} \cdot \mathrm{L}^{-}}^{1}\end{array}$} & \multicolumn{4}{|c|}{ Initial tank concentration } \\
\hline & & & & & & & Salt & Acid & Base & Electrode \\
\hline & & & & & & & $\begin{array}{c}\mathrm{mol} \cdot \mathrm{L}^{-} \\
1\end{array}$ & $\begin{array}{c}\mathrm{mol} \cdot \mathrm{L}^{-} \\
1\end{array}$ & $\begin{array}{c}\mathrm{mol} \cdot \mathrm{L}^{-} \\
1\end{array}$ & $\mathbf{m o l} \cdot \mathbf{L}^{-1}$ \\
\hline E-C & Constant & \multirow{3}{*}{ Continuous } & \multirow{3}{*}{$2^{\mathrm{a}}$} & \multirow{3}{*}{$1^{\mathrm{a}}$} & \multirow{2}{*}{$\mathrm{NaOH}$} & \multirow{4}{*}{1} & \multirow{4}{*}{0.5} & \multirow{4}{*}{1} & \multirow{4}{*}{1.5} & \multirow{2}{*}{0.5} \\
\hline E-V1 & \multirow{3}{*}{ Variable } & & & & & & & & & \\
\hline E-V2 & & & & & & & & & & 0.25 \\
\hline E-V3 & & $\begin{array}{c}\text { Semi- } \\
\text { continuous }\end{array}$ & $8^{\mathrm{b}}$ & $4^{\mathrm{c}}$ & $\mathrm{Na}_{2} \mathrm{SO}_{4}$ & & & & & 0.5 \\
\hline
\end{tabular}

${ }^{\mathrm{b}}$ It can be switched between $0 \mathrm{~mL} \cdot \mathrm{min}^{-1}$ and a fixed value of $8 \mathrm{~mL} \cdot \mathrm{min}^{-1}$ thus semi-continuous mode. The set point for the brine tank conductivity is $50 \mathrm{mS} \cdot \mathrm{cm}^{-1}$. A conductivity value below $50 \mathrm{mS} \cdot \mathrm{cm}^{-1}$ stops the peristaltic pump.

${ }^{\mathrm{c}}$ It can be switched between $0 \mathrm{~mL} \cdot \mathrm{min}^{-1}$ and a fixed value of $4 \mathrm{~mL} \cdot \mathrm{min}^{-1}$ thus semi-continuous mode. The set point for the acid tank pH is 0.1 . A pH value over $0.1 \mathrm{stops}$ the peristaltic pump. 


\section{Results and discussion}

An analysis of the production of acid and base and brine removal results for each of the four experiments performed is presented next. Once these results are discussed, an analysis of the Specific Energy Consumption regarding the production of acid ( $\mathrm{HCl})$ as the representative product $\left(\mathrm{SEC} \mathrm{HCl}\right.$ as $\mathrm{kWh} \cdot \mathrm{kg}^{-1} \mathrm{HCl}$ ) is assessed.

\subsection{Analysis of the production of acid and base and brine removal in continuous mode}

A summary of the average concentrations of $\mathrm{Cl}^{-}, \mathrm{Na}^{+}, \mathrm{SO}_{4}{ }^{2-}$ in the four tanks for the four experiments plus the standard deviation is presented in Table 4. The $\mathrm{pH}$ and conductivity values are reported in Table 5. Both under constant and variable current intensities, measured concentration values for the involved species can be reported as average values during the period of 30 hours.

E-C was used as a benchmark experiment. An overall $(0.55 \pm 0.04) \mathrm{mol} \cdot \mathrm{L}^{-1} \mathrm{Cl}^{-}$output salt concentration is obtained for the total period of 30 hours. A similar situation is observed for the acid compartment $(0.93 \pm 0.04) \mathrm{mol} \cdot \mathrm{L}^{-1} \mathrm{Cl}^{-}$and base compartment $(1.49 \pm 0.05) \mathrm{mol} \cdot \mathrm{L}^{-1} \mathrm{Na}^{+}$output base concentration. $\mathrm{Na}^{+}$cations in the acid compartment were below the detection limit. Consequently, it can be assured that the process is able to produce acid and base in a continuous mode under constant current intensity of $2.2 \mathrm{~A}$. A loss of $\mathrm{Na}^{+}$was observed in the electrolyte compartment thus the conductivity decreased too. Measurements of conductivity in the different compartments were in agreement with the previous profiles. Regarding $\mathrm{pH}$, the acid compartment presents values close to $0.08 \pm 0.04$ while the base compartment has a value close to $14.23 \pm 0.02$. The salt compartment is acidified at an average value of $1.02 \pm 0.11$. The fact that the initial concentration in the salt, acid and base tanks is selected in advance to fit the expected steady-state for the period of 30 hours must not be misleading. Using a flowrate of 1 $\mathrm{mL} \cdot \mathrm{min}^{-1}$ for the acid product, supposing no production of $\mathrm{H}^{+}$at all, it will result in a final concentration of $0.51 \mathrm{~mol} \cdot \mathrm{L}^{-1} \mathrm{H}^{+},(\mathrm{pH} \approx 0.3)$, using a non-steady-state simple mass balance. This value is well-below the obtained acid concentration of $(0.93 \pm 0.04) \mathrm{mol} \cdot \mathrm{L}^{-1}$ $\mathrm{Cl}^{-}$. A similar situation holds true for the base and salt tank. 
E-V1 introduces the effect of the variable current intensity due to the solar irradiation profile. The output $\mathrm{Cl}^{-}$concentration in the salt stream is almost constant for the period of 30 hours of the experiment: an overall $(0.47 \pm 0.01) \mathrm{mol} \cdot \mathrm{L}^{-1} \mathrm{Cl}^{-}$concentration is obtained when powered by the PV solar array simulator. The concentration of $\mathrm{Cl}^{-}$in the output acid stream remained in steady-state for the period of the experiment $((0.98 \pm 0.04)$ $\mathrm{mol} \cdot \mathrm{L}^{-1} \mathrm{Cl}^{-}$). A similar status is observed for the base compartment: a concentration of $(1.64 \pm 0.10) \mathrm{M} \mathrm{Na}^{+}$for the output base stream is obtained for the total period of E-V1. The loss of $\mathrm{Na}^{+}$in the electrolyte compartment leads to a noticeable increase in the output voltage on the $3^{\text {rd }}$ day (last 10 hours). Conductivity also supported the values observed for $\mathrm{Cl}^{-}$and $\mathrm{Na}^{+}$. The $\mathrm{pH}$ values in the acid and base compartments were in good agreement with the concentration of $\mathrm{Cl}^{-}(-0.06 \pm 0.03)$ and $\mathrm{Na}^{+}(14.23 \pm 0.03)$ respectively. Acidification of the salt compartment was also observed. It is noteworthy that a higher in E-V1, did not reveal an increase in the average $\mathrm{pH}$.

In E-V2, the output $\mathrm{Cl}^{-}$concentration is almost constant for the already period of 30 hours of the experiment: an overall $(0.47 \pm 0.03) \mathrm{M} \mathrm{Cl}^{-}$concentration is obtained when powered by the PV solar array simulator and swapping to $\mathrm{Na}_{2} \mathrm{SO}_{4}$ as the electrolyte. $\mathrm{Na}_{2} \mathrm{SO}_{4}$ was tested as an electrolyte to prevent the loss of conductivity. For the acid compartment, the average concentration was $(1.06 \pm 0.05) \mathrm{mol} \cdot \mathrm{L}^{-1} \mathrm{Cl}^{-}$. For the base compartment, the average concentration was $(1.55 \pm 0.05) \mathrm{mol} \cdot \mathrm{L}^{-1} \mathrm{Na}^{+} \cdot \mathrm{SO}_{4}{ }^{2-}$ concentration remained constant in the electrode tank $\left(0.23 \pm 0.01 \mathrm{~mol} \cdot \mathrm{L}^{-1} \mathrm{SO}_{4}{ }^{2-}\right)$ for the whole experiment. Due to the fact that no relevant losses of $\mathrm{Na}^{+}$were observed, conductivity in the compartments remained almost constant thus concentration was raised in E-V3 in order to reduce the total stack voltage. As the current intensity profile was equal to the one applied in E-V1, then the voltage profiles for the three days were quite similar due to an overall similar conductivity profile for the three days. In the acid tank, the $\mathrm{pH}$ values were around $-0.08 \pm 0.05$, and in the base tank $14.24 \pm 0.03$, which fits the concentrations of $\mathrm{Cl}^{-}$and $\mathrm{Na}^{+}$for the period of the experiment. Once again, the superior average current intensity compared to the value for $\mathrm{E}-\mathrm{C}$ did not end up into a decrease in the $\mathrm{pH}$ of the acid compartment but into a steady-state value.

E-V3 demonstrates the effect of the variable current intensity. Independent feedback control loops for the $\mathrm{pH}$ of the acid and the conductivity of the brine were used, with their own set-points. The hypothesis for E-V3 is that a larger input current intensity will be able to withdraw additional concentrated acid and base from each tank at the same 
concentration level. In fact, this way, crossover phenomenon is prevented thus a higher yield as SEC can be obtained as later demonstrated. The concentration of $\mathrm{Cl}^{-}$in the salt tank was almost constant during the period of the experiment with a value of $(0.40 \pm 0.01)$ $\mathrm{mol} \cdot \mathrm{L}^{-1} \mathrm{Cl}^{-}$. As in the other experiments, the potential amount of $\mathrm{Na}^{+}$in the $\mathrm{HCl}$ tank was below the detection limit. While in the experiments E-C, E-V1 and E-V2, the flowrate was fixed for both inputs streams during the period of 30 hours (continuous mode as shown in Table 3), in E-V3 the flowrate only uses two values for the acid: $0 \mathrm{~mL} \cdot \mathrm{min}^{-1}$ and $4 \mathrm{~mL} \cdot \mathrm{min}^{-1}$ and two values for the brine: $0 \mathrm{~mL} \cdot \mathrm{min}^{-1}$ and $8 \mathrm{~mL} \cdot \mathrm{min}^{-1}$. The concentration of $\mathrm{Cl}^{-}$and $\mathrm{Na}^{+}$in the acid and base compartment were also almost stable at values of $(0.96 \pm 0.05) \mathrm{mol} \cdot \mathrm{L}^{-1} \mathrm{Cl}^{-}$and $(1.50 \pm 0.05) \mathrm{M} \mathrm{Na}^{+}$. $\mathrm{SO}_{4}{ }^{2-}$ concentration remains constant in the electrode tank $\left.\left((0.47 \pm 0.02) \mathrm{mol} \cdot \mathrm{L}^{-1} \mathrm{SO}_{4}{ }^{2-}\right)\right)$. The $\mathrm{pH}$ values in the acid $(0.03 \pm 0.04)$ and base $(14.19 \pm 0.01)$ compartments were in agreement with the $\mathrm{Cl}^{-}$and $\mathrm{Na}^{+}$ concentration tanks respectively. Therefore, the acid control loop $(\mathrm{pH}<0.1)$ was active during the whole period of 30 hours $(\mathrm{pH}<0.1)$. Acidification of the salt compartment was also observed with values at $1.32 \pm 0.15$. No significant variations of the conductivity values were observed. Due to this conductivity stability, the total stack voltage profiles for the three days were quite similar. It is noteworthy that the concentration values were not due to the initial concentration of $\mathrm{HCl}$ and $\mathrm{NaOH}$ in the tanks. The 30 hours experimentation time guarantees that the liquid volume inside the tanks would be almost replaced by the diluted acid and base if the process would be not capable of producing them using the bipolar membranes as mentioned earlier in E-C. At a flowrate of 4 $\mathrm{mL} \cdot \mathrm{min}^{-1}$ and no production of $\mathrm{H}^{+}$, the theoretical final $\mathrm{pH}$ would be 0.86 , which is higher than the actual measured value $(0.03 \pm 0.04)$. 
Table 4. Summary of concentration of the main species for the four performed experiments. b.d.l. stands for below detection limit.

\begin{tabular}{|c|c|c|c|c|c|c|c|c|c|}
\hline \multirow{3}{*}{$\begin{array}{l}\text { Experiment } \\
\text { code }\end{array}$} & \multicolumn{4}{|c|}{ Steady-state concentration of chloride anion $\mathrm{Cl}^{-}$} & \multicolumn{4}{|c|}{$\begin{array}{l}\text { Steady-state concentration of chloride anion } \\
\mathrm{Na}^{+}\end{array}$} & \multirow{2}{*}{ 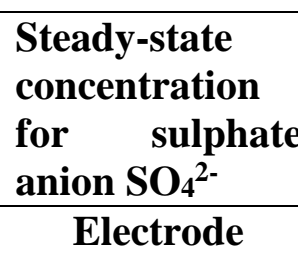 } \\
\hline & Salt & Acid & Base & Electrode & Salt & Acid & Base & Electrode & \\
\hline & $\mathbf{m o l} \cdot \mathbf{L}^{-1}$ & $\mathbf{m o l} \cdot \mathbf{L}^{-1}$ & $\mathbf{m o l} \cdot \mathbf{L}^{-1}$ & $\mathbf{m o l} \cdot \mathbf{L}^{-1}$ & $\mathbf{m o l} \cdot \mathbf{L}^{-1}$ & $\mathbf{m o l} \cdot \mathbf{L}^{-1}$ & $\mathbf{m o l} \cdot \mathbf{L}^{-1}$ & $\mathbf{m o l} \cdot \mathbf{L}^{-1}$ & $\mathbf{m o l} \cdot \mathbf{L}^{-1}$ \\
\hline E-C & $0.55 \pm 0.04$ & $0.93 \pm 0.04$ & $0.06 \pm 0.01$ & $0.05 \pm 0.01$ & $0.53 \pm 0.05$ & b.d.l. & $1.49 \pm 0.05$ & $0.39 \pm 0.09$ & - \\
\hline E-V1 & $0.47 \pm 0.01$ & $0.98 \pm 0.04$ & $0.09 \pm 0.01$ & $0.06 \pm 0.01$ & $0.40 \pm 0.03$ & b.d.l. & $1.64 \pm 0.10$ & $0.24 \pm 0.20$ & - \\
\hline E-V2 & $0.47 \pm 0.03$ & $1.06 \pm 0.05$ & $0.08 \pm 0.01$ & $0.05 \pm 0.01$ & $0.38 \pm 0.02$ & b.d.l. & $1.55 \pm 0.05$ & $0.32 \pm 0.03$ & $0.23 \pm 0.01$ \\
\hline E-V3 & $0.40 \pm 0.01$ & $0.96 \pm 0.05$ & $0.13 \pm 0.01$ & $0.07 \pm 0.00$ & $0.35 \pm 0.02$ & b.d.l. & $1.50 \pm 0.05$ & $0.40 \pm 0.01$ & $0.47 \pm 0.02$ \\
\hline
\end{tabular}

Table 5. Summary of pH and conductivity values for the four performed experiments

\begin{tabular}{|c|c|c|c|c|c|c|c|c|}
\hline \multirow{3}{*}{$\begin{array}{l}\text { Experiment } \\
\text { code }\end{array}$} & \multicolumn{4}{|l|}{ pH } & \multicolumn{4}{|c|}{ Conductivity } \\
\hline & Salt & Acid & Base & Electrode & Salt & Acid & Base & Electrode \\
\hline & & & & & $\mathrm{mS} \cdot \mathrm{cm}^{-1}$ & $\mathrm{mS} \cdot \mathbf{c m}^{-1}$ & $\mathrm{mS} \cdot \mathbf{c m}^{-1}$ & $\mathrm{mS} \cdot \mathbf{c m}^{-1}$ \\
\hline E-C & $1.02 \pm 0.11$ & $-0.08 \pm 0.04$ & $14.23 \pm 0.02$ & $13.66 \pm 0.12$ & $62 \pm 5$ & $320 \pm 15$ & $242 \pm 13$ & $73 \pm 17$ \\
\hline E-V1 & $1.18 \pm 0.08$ & $-0.06 \pm 0.03$ & $14.24 \pm 0.03$ & $13.27 \pm 0.46$ & $56 \pm 4$ & $349 \pm 16$ & $263 \pm 12$ & $47 \pm 34$ \\
\hline E-V2 & $1.12 \pm 0.12$ & $-0.08 \pm 0.05$ & $14.24 \pm 0.03$ & $0.99 \pm 0.24$ & $62 \pm 7$ & $367 \pm 19$ & $270 \pm 14$ & $41 \pm 4$ \\
\hline E-V3 & $1.32 \pm 0.15$ & $0.03 \pm 0.04$ & $14.19 \pm 0.01$ & $0.88 \pm 0.37$ & $43 \pm 1$ & $319 \pm 15$ & $243 \pm 17$ & $64 \pm 8$ \\
\hline
\end{tabular}


403

$$
S E C_{H C l}=\frac{\int_{t=0}^{t=t_{E}} U I d t}{Q_{H C l} P M_{H C l} \bar{C}_{H C l} t_{E}}
$$

404

405

406

407

408

409

410 1: possible.

\subsection{Specific energy consumption for the acid production}

The energy performance of the EDBM powered by variable (and constant as reference) current intensity has been quantified in terms of the Specific Energy Consumption (SEC) applied to the production of $\mathrm{HCl}$ from model brine solutions at lab scale. On the other hand, as variable current intensity simulating the behavior of a PV solar array is applied, it is of interest to analyze the theoretical PV solar conversion efficiency. Thus, two energy-related metrics are taken into account to characterize the energy performance of the process, which is directly related to its carbon footprint.

The Specific Energy Consumption $\mathrm{SEC}_{\mathrm{HCl}}$ represents the energy used by the EDBM stack to produce one unit of mass of $\mathrm{HCl}$ at a specified concentration. As two products are obtained in EDBM, $\mathrm{HCl}$ was chosen over $\mathrm{NaOH}$ due to the fact that most of the references are related to the acid compartment rather than the base compartment as reported in Table 6. The $\mathrm{SEC}_{\mathrm{HCl}}$ (expressed as $\mathrm{kWh} \cdot \mathrm{kg}^{-1} \mathrm{HCl}$ ) is then calculated as in Eq.

Where $\mathrm{U}$ is the total stack voltage (V), I is the current intensity (A), Q $\mathrm{HCl}$ is the flowrate of produced $\mathrm{HCl}\left(\mathrm{L}^{-} \mathrm{h}^{-1}\right)$ by the overflow, $\mathrm{PM}_{\mathrm{HCl}}$ is the molecular weight of $\mathrm{HC}_{\mathrm{L}}\left(\mathrm{g} \cdot \mathrm{mol}^{-}\right.$ $\left.{ }^{1}\right), \overline{C_{H C l}}$ is the average concentration of $\mathrm{HCl}$ during the experiment $\left(\mathrm{mol} \cdot \mathrm{L}^{-1}\right)$ as reported in Table 3), $t_{\mathrm{E}}$ is the total time of the experiment (30 hours), and $\mathrm{t}$ is the time. The main hypothesis is that a higher $\mathrm{Q}_{\mathrm{HCl}}$ is possible while keeping $\overline{C_{H C l}}$ relatively stable, thus a lower $\mathrm{SEC}_{\mathrm{HCl}}$ would be obtained if the same amount of energy is injected. The rationale here is that the larger injected current intensity can be used for this purpose avoiding the negative effect of the crossover phenomenon between the compartments. The relationship of the total voltage (U) and current intensity (I) in the cell will be determined by the overall ohmic resistance, which have to include the ionic resistance due to the membranes [24]. Therefore, a high conductivity is necessary to maintain the total voltage as low as 


\begin{tabular}{|c|c|c|c|c|c|c|c|c|}
\hline Experiment & Reference & SECHCl & Produced acid & $\begin{array}{l}\text { HCl } \\
\text { concentration }\end{array}$ & $\begin{array}{l}\text { Average } \\
\text { current } \\
\text { density }\end{array}$ & $\begin{array}{l}\text { Bipolar } \\
\text { membrane }\end{array}$ & $\begin{array}{l}\text { Operation } \\
\text { mode and } \\
\text { time (min) }\end{array}$ & $\begin{array}{l}\text { Power } \\
\text { source }\end{array}$ \\
\hline & & $\begin{array}{l}\text { kWh· } \mathbf{k g}^{-1} \\
\text { HCl }\end{array}$ & & $\mathbf{m o l} \cdot \mathbf{L}^{-1}$ & $A \cdot \mathbf{m}^{-2}$ & & & \\
\hline $\mathrm{E}-\mathrm{C}$ & \multirow[t]{2}{*}{ This work } & 7.3 & \multirow[t]{2}{*}{$\mathrm{HCl}$} & 0.93 & 220 & \multirow[t]{2}{*}{ Fumasep FBM } & \multirow[t]{2}{*}{ Cnt } & $\mathrm{C}$ \\
\hline \multirow[t]{6}{*}{ E-V3 } & & 4.4 & & 0.96 & 360 & & & $\mathrm{~V}$ \\
\hline & \multirow[t]{3}{*}[2]{} & 7.5 & \multirow[t]{3}{*}{$\mathrm{HCl}+\mathrm{H}_{2} \mathrm{SO}_{4}$} & \multirow[t]{3}{*}{1.0} & 220 & \multirow[t]{3}{*}{ Fumatech } & \multirow[t]{3}{*}{ B / Cnt / 150} & \multirow[t]{5}{*}{$\mathrm{C}$} \\
\hline & & 8.0 & & & 450 & & & \\
\hline & & 8.3 & & & 570 & & & \\
\hline & [25] & 4.2 & $\mathrm{HCl}+\mathrm{H}_{2} \mathrm{SO}_{4}$ & 1.5 & - & PC BP & Cnt & \\
\hline & [26] & 3.72 & $\begin{array}{l}\text { Alpha-ketoglutaric } \\
\text { acid }\end{array}$ & 0.033 & 65 & $\begin{array}{l}\text { PC 200bip } \\
\text { (PCCell) }\end{array}$ & $\mathrm{B} / 180$ & \\
\hline
\end{tabular}

Table 6. Specific energy consumption of the production of $\mathrm{HCl} \mathrm{SEC} \mathrm{HCl}\left(\mathrm{kWh} \cdot \mathrm{kg}^{-1} \mathrm{HCl}\right)$ for the four performed experiments and selected references. B stands for batch and Cnt for continuous. C stands for constant current intensity (Grid Mix) and V stands for Variable current intensity (PV array simulator). 
Table 6 reports the values of the $\mathrm{SEC}_{\mathrm{HCl}}$ for $\mathrm{E}-\mathrm{C}$ and $\mathrm{E}-\mathrm{V} 3$ experiments, including

424 additional SEC values of interest from selected references. As it was expected and confirmed by the experimental results, E-V3 shown the lowest SEC, which was 4.4

$426 \mathrm{kWh} \cdot \mathrm{kg}^{-1} \mathrm{HCl}$ among the variable current intensity experiments, reaching values even 427 below the $7.3 \mathrm{kWh} \cdot \mathrm{kg}^{-1} \mathrm{HCl}$ obtained for E-C. This value for the $\mathrm{SEC}_{\mathrm{HCl}}$ of E-C shows 428 that the applied current density of $220 \mathrm{~A} \cdot \mathrm{m}^{-2}$ used as a reference from previous work (2.2 429 A) could be potentially reduced. SEC values reported in [2] fits those presented here for 430 a similar range of constant current densities and $\mathrm{HCl}$ and $\mathrm{H}_{2} \mathrm{SO}_{4}$ concentrations. It is 431 noteworthy that each individual experimental set-up (different individual studies) can explain the differences in the influence of the current density in the SEC values. The key element of the reduction in the $\mathrm{SEC}_{\mathrm{HCl}}$ has been the increase of the product flowrate by four times according to Eq. 1. The feedback control loop for the acid helped at increasing the production of $\mathrm{HCl}$ without compromising its concentration. Figure 4 displays the $\mathrm{SEC}_{\mathrm{HCl}}$ values for the three variable experiments and its comparison versus the reference experiment E-C. SEC $\mathrm{HCl}$ values of $22.9 \mathrm{kWh} \cdot \mathrm{kg}^{-1} \mathrm{HCl}$ and $18.7 \mathrm{kWh} \cdot \mathrm{kg}^{-1} \mathrm{HCl}$ were obtained for E-V1 and E-V2 respectively. As it was expected, due to the fact that the acid concentration was similar to the benchmark experiment E-C and a higher current density was applied (350 A $\cdot \mathrm{m}^{-2}$ and $360 \mathrm{~A} \cdot \mathrm{m}^{-2}$ instead $220 \mathrm{~A} \cdot \mathrm{m}^{-2}$ ), the $\mathrm{SEC}_{\mathrm{HCl}}$ increased in regards to the value for $\mathrm{E}-\mathrm{C}$.

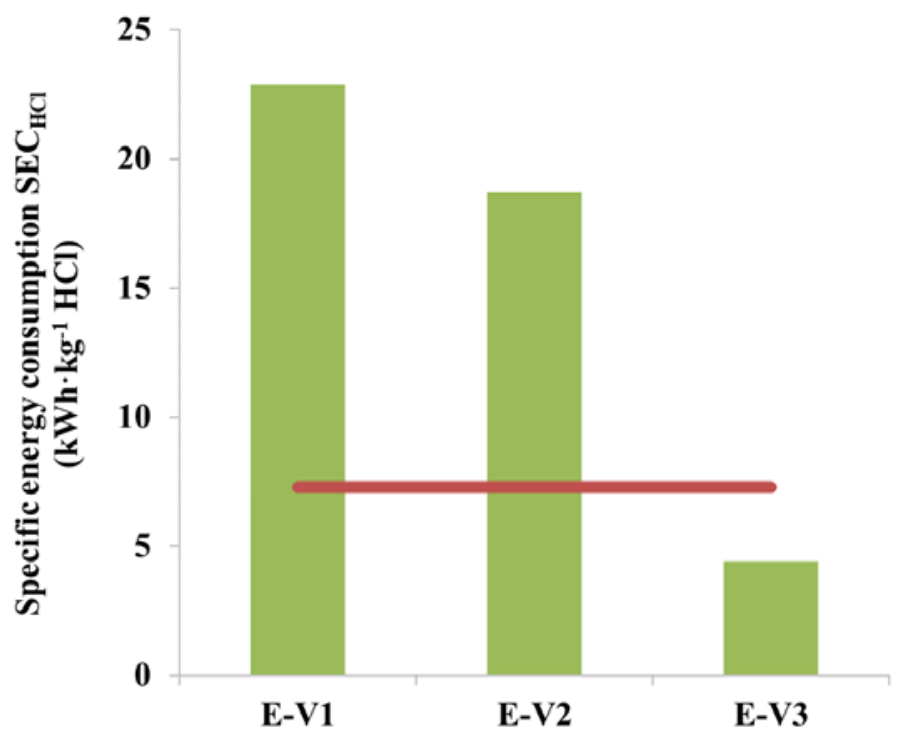

Figure 4. Comparison of the $\mathrm{SEC}_{\mathrm{HCl}}$ for the variable experiments $\mathrm{E}-\mathrm{V} 1, \mathrm{E}-\mathrm{V} 2$ and $\mathrm{E}-\mathrm{V} 3$. The red line is the $\mathrm{SEC} \mathrm{HCl}$ of $\mathrm{E}-\mathrm{C}\left(7.3 \mathrm{kWh} \cdot \mathrm{kg}^{-1} \mathrm{HCl}\right)$, which is the reference experiment. 
443 As it was mentioned earlier, the loss of conductivity in the electrolyte compartment 444 led to an overall increase in the ohmic resistance, which is visualized here in terms of a 445 relevant increase in the total cell voltage. Figure 5 displays the value of total current 446 intensity and total cell voltage for the four experiments performed. The effect is especially 447 important in E-V1. While voltage in the first 20 hours of operation topped $10.9 \mathrm{~V}$ in the 448 central hours, the maximum value in the last 10 hours reached $28.9 \mathrm{~V}$. As a result, the $449 \mathrm{SEC}_{\mathrm{HCl}}$ increased up to $35.2 \mathrm{kWh} \cdot \mathrm{kg}^{-1} \mathrm{HCl}$ for the last 10 hours, which is around five 450 times the value obtained for $\mathrm{E}-\mathrm{C}$. The swapping to $\mathrm{Na}_{2} \mathrm{SO}_{4}$ is justified here, as the voltage 451 was predictable in E-V2 and E-V3. The conductivity was measured and no relevant 452 variations were observed for E-V2 and E-V3. The peak voltage value in E-V2 (17 V) and 453 the valley voltage value in the central 10 hours of E-V3 (around $9 \mathrm{~V}$ ) compared to the 454 other 2 days (12 V) are suggested to be due to the temporal accumulation of bubbles 455 inside the cell. This formation may alter the total cell voltage without being influenced 456 by the solution conductivity [27]. Also, the swelling of the membranes can have a 457 potential contribution to the overall resistance. Further research is suggested to determine 458 the influence of these variables, especially bubbles formation, in order to predict the 459 overall ohmic resistance.

a)

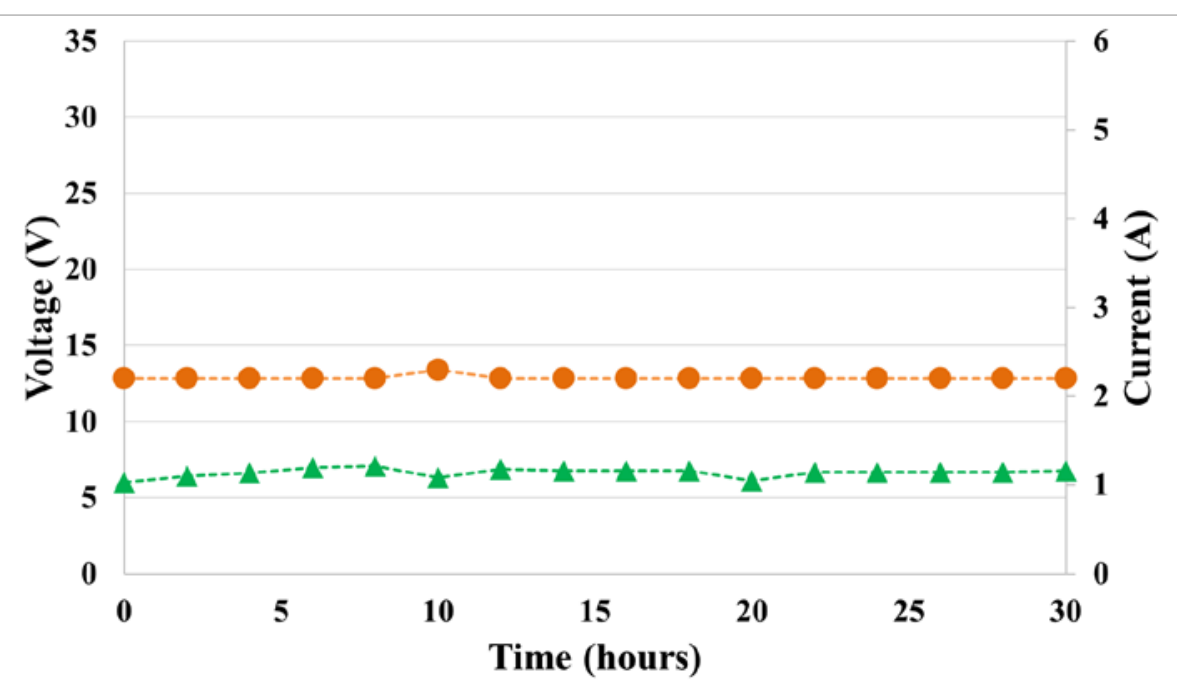

b) 


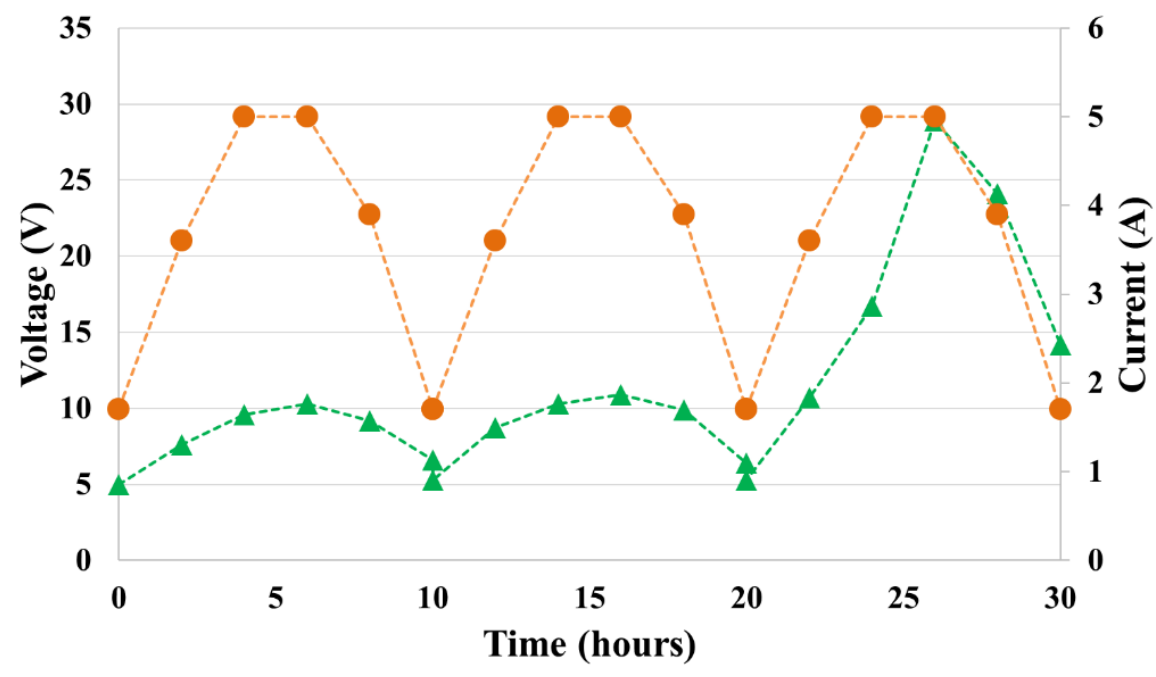

c)

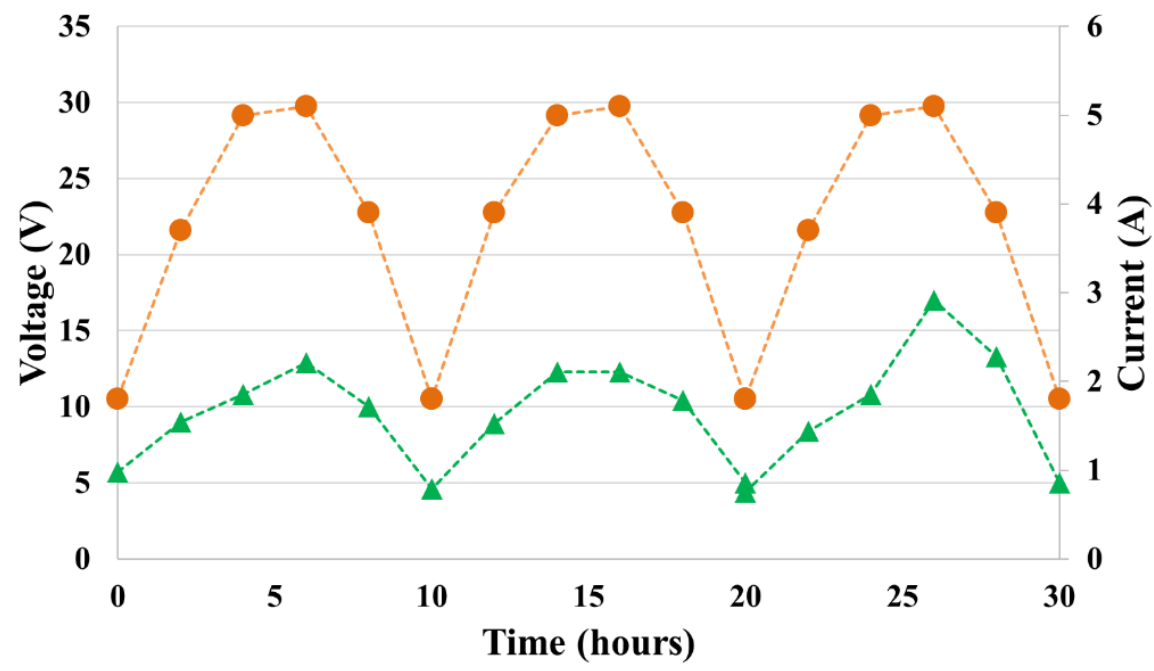

d)

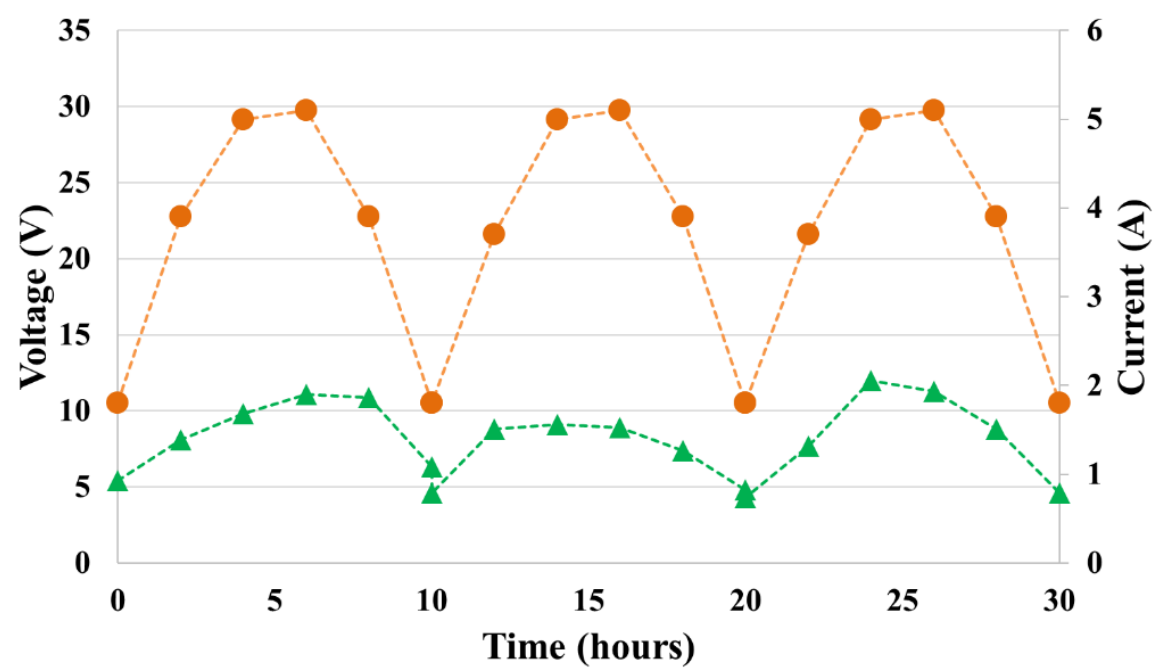

Figure 5. Temporal evolution of the total applied current and total cell voltage corresponding to the four compartments. The triangles $(\Delta)$ represents the voltage on the 
left vertical axis and the full circles (•) the current intensity in the right vertical axis. The doted line does not represent a simulation. The figures represent: a) E-C, b) E-V1, c) EV2 and d) E-V3.

461

462

463

464

465

466

467

468

469

470

471

472

473

474

475

476

477

478

479

The second relevant energy metric is the theoretical efficiency of the PV solar array responsible for the variable current intensity. The solar irradiation profile is responsible for the variable current intensity injected into the EDBM lab-scale plant. Therefore, due to the overall ohmic resistance of the stack, a pair U-I is established. The efficiency of the PV solar array $\eta(\%)$ is defined as in Eq. 2:

$$
\eta=\frac{\int_{t=0}^{t=t_{E}} G A_{P V} d t}{\int_{t=0}^{t=t_{E}} U I d t} \cdot 100
$$

Where $G$ is the defined-by-the-user solar irradiation -for the month and selected location over a certain orientation and inclination angle- $\left(\mathrm{W} \cdot \mathrm{m}^{-2}\right)$, and $A_{\mathrm{PV}}$ is the total exposed PV area $\left(\mathrm{m}^{2}\right)$. For the simulated PV module, the maximum efficiency value $\eta_{M A X}$ is $14.2 \%$ and the $A_{P V}$ as $1.125 \mathrm{~m}^{2}$ as cited in Table 7, which are sourced from [4].

Table 7. Estimated efficiencies for the three performed experiments using variable current intensity.

\begin{tabular}{|l|l|l|l|l|}
\hline Experiment & $\boldsymbol{\eta}$ & $\boldsymbol{\eta} \cdot \boldsymbol{\eta}_{\text {max }}{ }^{-1}$ & $\begin{array}{l}\text { Energy reaching the } \\
\text { surface of the PV } \\
\text { modules } \\
\int_{\boldsymbol{t}=\boldsymbol{t}_{\boldsymbol{E}}} \boldsymbol{G A}_{\boldsymbol{P V}} \boldsymbol{d} \boldsymbol{t}\end{array}$ & $\begin{array}{l}\text { Energy collected } \\
\text { by EDBM } \\
\text { stack }\end{array}$ \\
\hline & $\mathbf{( \% )}$ & $\mathbf{( \% )}$ & $\mathrm{kWh}$ & $\mathrm{kWh}$ \\
\hline E-V1 & 6.3 & 44 & 23.3 & 1.47 \\
\hline E-V2 & 5.6 & 39 & 23.3 & 1.30 \\
\hline E-V3 & 4.6 & 32 & 23.3 & 1.08 \\
\hline
\end{tabular}

The efficiency of the transformation of the simulated solar profile into energy for the EDBM process is summarized in Table 7 for the three performed experiments. From Table 7 it is clear that the obtained $\eta$ values ranges from $4.6 \%$ to $6.3 \%$, thus the PV solar 
module is working far from the maximum operating point, as the simulated maximum $\eta$ is around $14.2 \%$. Indeed, barely half of the maximum efficiency (44\%) is reached in EV1. This value is far away from the efficiency of the champion modules currently available for crystalline technology over $24 \%$ [28]. It is important to highlight the fact that the largest efficiency is obtained for the experiments which performs worst in SEC terms. This due to the fact that in E-V1, the overall ohmic resistance moves the operating point (pair current-voltage) to the voltage of the maximum power point, around $34 \mathrm{~V}$. Because of the mismatch between the maximum power operating point U-I (34.4 V and $4.65 \mathrm{~A}$ ) and the range of the operating point during the experiments (see Figure 5), this efficiency will be below the maximum value. This is an important metric as the larger the deviation from the maximum operating point, the larger the needs of real PV power for satisfying the demand, which entails of course additional investment cost. The use of maximum power point trackers will help at using the PV module at its maximum performance.

\section{Conclusions}

A significant reduction of the specific energy consumption of the $\mathrm{HCl}$ production from the described EDBM process based in a feedback control loop under variable current intensity has been demonstrated. The performance of the process has been tested using: 1) constant current intensity as reference, 2) variable current intensity from a PV solar array simulator. Even under variable current intensity, a constant concentration around 1 $\mathrm{mol} \cdot \mathrm{L}^{-1} \mathrm{HCl}$ has been obtained. The PV solar energy experiment with feedback control loop lead to a noticeable drop from the benchmark value of $7.3 \mathrm{kWh} \cdot \mathrm{kg}^{-1} \mathrm{HCl}$ to the improved value of $4.4 \mathrm{kWh} \cdot \mathrm{kg}^{-1} \mathrm{HCl}$. This reduction in the energy consumption is particularly relevant if compared against a variable current intensity with no control loop. This work contributes to the advance in the integration of EDBM and variable power systems and the technical conditions for its viability. Future works point to the integration of maximum power point trackers to improve the PV solar efficiency of real systems and the modeling of the process as a previous step to its optimization from a process system engineering point of view. 


\section{Acknowledgements}

Financial support from MICINN under project CTM2014-57833-R is gratefully acknowledged. Marta Herrero-Gonzalez thanks the MICINN for FPI grant BES-201507350 .

\section{References}

[1] D. Cunningham, IPPC, BAT, and voluntary agreements, J. Hazard. Mater. 78 (2000) 105-121. doi:10.1016/S0304-3894(00)00219-3.

[2] Y. Yang, X. Gao, A. Fan, L. Fu, C. Gao, An innovative beneficial reuse of seawater concentrate using bipolar membrane electrodialysis, J. Memb. Sci. 449 (2014) 119-126. doi:10.1016/j.memsci.2013.07.066.

[3] C. Fernandez-Gonzalez, A. Dominguez-Ramos, R. Ibañez, A. Irabien, Sustainability assessment of electrodialysis powered by photovoltaic solar energy for freshwater production, Renew. Sustain. Energy Rev. 47 (2015) 604-615. doi:10.1016/j.rser.2015.03.018.

[4] A. Dominguez-Ramos, R. Aldaco, A. Irabien, Photovoltaic solar electrochemical oxidation (PSEO) for treatment of lignosulfonate wastewater, J. Chem. Technol. Biotechnol. 85 (2010). doi:10.1002/jctb.2370.

[5] D. Valero, J. Ortiz, E. Exposito, V. Montiel, A. Aldaz, Electrocoagulation of a synthetic textile effluent powered by photovoltaic energy without batteries: Direct connection behaviour, Sol. Energy Mater. Sol. Cells. 92 (2008) 291-297. doi:10.1016/j.solmat.2007.09.006.

[6] Z. Amor, B. Bariou, N. Mameri, M. Taky, S. Nicolas, A. Elmidaoui, Fluoride removal from brackish water by electrodialysis, Desalination. 133 (2001) 215223. doi:10.1016/S0011-9164(01)00102-3.

[7] P. Tsiakis, L.G. Papageorgiou, Optimal design of an electrodialysis brackish water desalination plant, Desalination. 173 (2005) 173-186. doi:10.1016/j.desal.2004.08.031.

[8] J.M. Ortiz, E. Expósito, F. Gallud, V. García-García, V. Montiel, A. Aldaz, Electrodialysis of brackish water powered by photovoltaic energy without batteries: direct connection behaviour, Desalination. 208 (2007) 89-100. doi:10.1016/j.desal.2006.05.026. 
[9] M. Reig, S. Casas, C. Aladjem, C. Valderrama, O. Gibert, F. Valero, C.M. Centeno, E. Larrotcha, J.L. Cortina, Concentration of $\mathrm{NaCl}$ from seawater reverse osmosis brines for the chlor-alkali industry by electrodialysis, Desalination. 342 (2014) 107-117. doi:10.1016/j.desal.2013.12.021.

[10] J. Ortiz, E. Exposito, F. Gallud, V. Garcia-Garcia, V. Montiel, A. Aldaz, Desalination of underground brackish waters using an electrodialysis system powered directly by photovoltaic energy, Sol. Energy Mater. Sol. Cells. 92 (2008) 1677-1688. doi:10.1016/j.solmat.2008.07.020.

[11] Y. Tanaka, R. Ehara, S. Itoi, T. Goto, Ion-exchange membrane electrodialytic salt production using brine discharged from a reverse osmosis seawater desalination plant, J. Memb. Sci. 222 (2003) 71-86. doi:10.1016/S0376-7388(03)00217-5.

[12] M. Fidaleo, M. Moresi, Electrodialytic desalting of model concentrated $\mathrm{NaCl}$ brines as such or enriched with a non-electrolyte osmotic component, J. Memb. Sci. 367 (2011) 220-232. doi:10.1016/j.memsci.2010.10.069.

[13] M. Mier, R. Ibañez, I. Ortiz, Influence of ion concentration on the kinetics of electrodialysis with bipolar membranes, Sep. Purif. Technol. 59 (2008) 197-205. doi:10.1016/j.seppur.2007.06.015.

[14] C. Fernandez-Gonzalez, A. Dominguez-Ramos, R. Ibañez, Y. Chen, A. Irabien, Valorization of desalination brines by electrodialysis with bipolar membranes using nanocomposite anion exchange membranes, Desalination. 406 (2017) 1624. doi:10.1016/j.desal.2016.07.033.

[15] M. Reig, S. Casas, O. Gibert, C. Valderrama, J.L. Cortina, Integration of nanofiltration and bipolar electrodialysis for valorization of seawater desalination brines: Production of drinking and waste water treatment chemicals, Desalination. 382 (2016) 13-20. doi:10.1016/j.desal.2015.12.013.

[16] Y. Wang, A. Wang, X. Zhang, T. Xu, Simulation of electrodialysis with bipolar membranes: Estimation of process performance and energy consumption, Ind. Eng. Chem. Res. 50 (2011) 13911-13921. doi:10.1021/ie200467s.

[17] Y. Lorrain, G. Pourcelly, C. Gavach, Influence of cations on the proton leakage through anion-exchange membranes, J. Memb. Sci. 110 (1996) 181-190.

[18] T. Xu, C. Huang, Electrodialysis-Based separation technologies: A critical review, AIChE J. 54 (2008) 3147-3159. doi:10.1002/aic.11643.

[19] R. Ibáñez, A. Pérez-González, P. Gómez, A.M. Urtiaga, I. Ortiz, Acid and base recovery from softened reverse osmosis (RO) brines. Experimental assessment 
using model concentrates, Desalination. 309 (2013) 165-170. doi:10.1016/j.desal.2012.10.006.

[20] E. Alvarez-Guerra, A. Dominguez-Ramos, A. Irabien, Photovoltaic solar electrooxidation (PSEO) process for wastewater treatment, Chem. Eng. J. 170 (2011). doi:10.1016/j.cej.2011.02.043.

[21] R. Ibañez, A. Perez-Gonzalez, P. Gomez, A.M. Urtiaga, I. Ortiz, Acid and base recovery from softened reverse osmosis (RO) brines. Experimental assessment using model concentrates, Desalination. 309 (2013) 165-170. doi:10.1016/j.desal.2012.10.006.

[22] JRC’s Directorate C Energy Transport and Climate, PVGIS, (n.d.). http://re.jrc.ec.europa.eu/pvgis/ (accessed April 21, 2017).

[23] S.R. Downward, R. Taylor, An assessment of Spain's Programa AGUA and its implications for sustainable water management in the province of Almer??a, southeast Spain, J. Environ. Manage. 82 (2007) 277-289. doi:10.1016/j.jenvman.2005.12.015.

[24] B. Zhang, J.G. Hong, S. Xie, S. Xia, Y. Chen, An integrative modeling and experimental study on the ionic resistance of ion-exchange membranes, J. Memb. Sci. 524 (2017) 362-369. doi:10.1016/j.memsci.2016.11.050.

[25] M. Reig, C. Valderrama, O. Gibert, J.L. Cortina, Selectrodialysis and bipolar membrane electrodialysis combination for industrial process brines treatment: Monovalent-divalent ions separation and acid and base production, Desalination. 399 (2016) 88-95. doi:10.1016/j.desal.2016.08.010.

[26] M. Szczygielda, K. Prochaska, Alpha-ketoglutaric acid production using electrodialysis with bipolar membrane, J. Memb. Sci. 536 (2017) 37-43. doi:10.1016/j.memsci.2017.04.059.

[27] Helmut, Vogt, Gerhard, Kreysa, S. Vasudevan, Rolf, Wüthrich, J. D., Abou Ziki, R. El-Haddad, Ullmann's Enciclopedia of Industrial Chemistry, in: Wiley-VCH Verlag GmbH \& Co (Ed.), 2013. doi:10.1002/14356007.109.

[28] M.A. Green, K. Emery, Y. Hishikawa, W. Warta, E.D. Dunlop, D.H. Levi, A.W.Y. Ho-Baillie, Solar cell efficiency tables (version 49), Prog. Photovoltaics Res. Appl. 25 (2017) 3-13. doi:10.1002/pip.2855. 